\title{
Analysis of students' metacognition level in solving scientific literacy on the topic of static fluid
}

\author{
Zakaria Sandy Pamungkas ${ }^{1}$, Nonoh Siti Aminah ${ }^{2}$, Fahru Nurosyid ${ }^{3}$ \\ 1,2Physics Education of Post Graduate Program, Sebelas Maret University, Indonesia \\ ${ }^{3}$ Physics Departement of Post Graduate Program, Sebelas Maret University, Indonesia
}

\begin{tabular}{l} 
Article Info \\
\hline Article history: \\
Received May 28, 2018 \\
Revised Nov 13, 2018 \\
Accepted Jan 02, 2019 \\
\hline
\end{tabular}

Keywords:

Metacognition level

Scientific literacy

Static fluid

\begin{abstract}
The purpose of this study is to describe students' metacognition level in solving scientific literacy. This research use the descriptive method. The subject of this research is 99 students of grade XI in SMA Batik 2 Surakarta. Data collection methods used are test methods which its instruments based on an indicator of scientific literacy and metacognition ability. Data analysis techniques use quantitative descriptive analysis. The results showed that the achievement of scientific literacy in science as a body of knowledge, science as a way of thinking, science as a way of investigating, and science as an interaction between technology and society is still low at below $35 \%$. This is due to $84 \%$ student occupy in low metacognition level that is $30 \%$ students in tacit use level, 54\% students in aware use level, and only $16 \%$ students occupy in high metacognition level that is in strategic use level.
\end{abstract}

Copyright $\odot 2019$ Institute of Advanced Engineering and Science. All rights reserved.

\section{Corresponding Author:}

Zakaria Sandy Pamungkas,

Physics Education of Post Graduate Program,

Sebelas Maret University,

Ir. Sutami Street Number 36A, Kentingan Jebres, Surakarta 57126, Indonesia.

Email: pamungkaszakaria@student.uns.ac.id

\section{INTRODUCTION}

Indonesia is currently facing the era of globalization. One of the characteristics of the era of globalization is the rapid development of science and technology. Advances in science and technology have had an impact on the development of education in Indonesia [1]. The development of the world of education can be seen through renewal in the education system to balance the progress of science and technology globally. This is because education can be a force for change to get better. The changes are expected to produce quality learners with a demonstrated attitude of science literacy. Literacy of science aims at developing the scholarly thinking of learners [2]. Furthermore, scientific literacy is very important mastered by students in relation to how they perceive the environment, health, economy, and the problems of modern society [3].

The term of scientific literacy has been used in the literature for more than four-decade, although not always with the same meaning of scientific literacy [4, 5]. Science literacy means appreciation of science by enhancing the components of learning within themselves in order to contribute to the social environment [6]. According to DeBoer scientific literacy means understanding science and its application to the needs of society [7]. Chiapetta and Udeani more specifically explain scientific literacy into four themes or category of science: science a body of knowledge, science a way of thinking, science a way of investigating, an interaction of science, technology, and society $[8,9]$.

Science a body of knowledge discusses facts, concepts, principles, laws, theories, etc. Science a way of thinking gives an overview of science in general and scientists especially in conducting investigations. science a way of investigating gives problems to stimulate thinking and doing something by assigning students to "investigate". Interaction of science, technology and society provides an overview of the impact 
or impact of science on society. Referring to the four themes / dimensions of science literacy put forward, then the indicator dimension of science literacy in each category can be seen in Table 1.

Table 1. Indicator for Each Category of Scientific Literacy

\begin{tabular}{ccl}
\hline No $\quad$ Category of Scientific Literacy & \multicolumn{1}{c}{ Indicator of Scientific Literacy for Each Category } \\
\hline 1 & science a body of knowledge, & (1) Facts, concepts, principles and laws of physics. \\
& (2) Hypotheses, theories and models of physics. \\
& (3) Situations / questions that require students to remember knowledge or information. \\
& (1) Direct students to answer questions through the use of materials. \\
& (2) Directing students to make calculations. \\
& (3) Directing students to explain the answers. \\
& (4) Involving students in experiments or thinking activities. \\
& (1) Require students to answer questions through the use of graphs, tables, and \\
& (2) Provide a cause and effect relationship. \\
& (3) Discuss facts and evidence. \\
& (4) Presents scientific method and problem solving. \\
interaction of science, & (1) Describe the usefulness of science and technology for society. \\
technology and society & (2) Demonstrate the negative effects of science and technology for society. \\
& (3) Discuss social issues relating to science or technology. \\
& (4) Mention of careers and jobs in science and technology.
\end{tabular}

One of the factors that influence students ability in solving science literacy problem is metacognition level. This is due to metacognition affects the learning process of a person [10]. Metacognition is defined as thinking about thinking [11]. Metacognition ability is the ability to reflect on something that is being considered. Metacognition plays an important role in regulating and controlling one's cognitive processes in learning and thinking more effectively and efficiently [12]. Metacognition ability is able to regulate the cognition of learners in learning activities [13-15]. Some important steps relating to metacognition processes that can help students solve problems) are: (1) identifying the problem, identifying and defining elements of the given situation, (2) representing (3) planning how to implement it, deciding on the steps, (4) evaluating the results and completion made [16].

Metacognition skills can help students recognize that physics requires logical reasoning in solving a problem that needs to be improved. Students need to be aware of every step of problem-solving in order to improve their metabolic skills. But each student has different metacognition skills in solving problems. There are 4 levels of metacognition capabilities, namely tacit use, aware use, strategic use and reflective use [17].

Students at tacit level solve problems without thinking in making decisions. In this case, the student does not answer the question (procedural knowledge) or answer the question but not according to the question. This is because students do not understand the question (declarative knowledge), so that students only answer in trial and error and answer in solving the problem. Students at the aware use level are aware of their own thought processes. This can be seen from the way students use prior knowledge to connect with the material (declarative knowledge). Students try to link the information they have to determine the problemsolving steps (procedural knowledge).

Students at the strategic use level are able to organize thinking processes to improve the accuracy of their thinking. In this case, the student is aware of her own thought process by using specific strategies that can improve the accuracy of her thinking. In this case, students are aware and able to select specific strategies or skills to solve the problem but can not explain the reason why to choose the step. Students at the reflective use level are aware of their own thought processes. This can be seen from the way students use prior knowledge to connect with the material (declarative knowledge). Students at this level can reflect on the thinking process before and after or during the process of solving the problem. Then consider the continuation and improvement of his thinking results so that the problem-solving answers are highly structured (procedural knowledge) because of students immediately correct when there are fewer steps. Students at this level can also explain the reasons why they chose to solve the problem.

Based on the description, it can be concluded that the metacognition level can to improve student skills in solving scientific literacy. Therefore it's important to analyze students' metacognition level in solving scientific literacy. The results of the analysis can be used as a reference or evaluation base for teachers to determine the appropriate learning to improve the quality of students.

\section{RESEARCH METHOD}

The type of this research is quantitative descriptive research. The method used in this research is survey method. This research uses survey research procedure by Biemer and Lyberg: 1) Research objective, 
2) Concepts, 3) Questioner, 4) Population, 5) Sampling, 6) Data collection, 7) Data processing, 8) Interpretation [18]. This research was conducted in the even semester of academic year 2017/2018 in SMA Batik 2 Surakarta. The sample in this research is the 99 students of grade XI IPA SMA Batik 2 Surakarta.

Data collection methods used were test and questionnaire. The instruments used in this research are test sheets and questionnaires. The test sheet is used to find out the profile of students' critical thinking ability in solving the science literacy problem based on metacognition ability level. The questionnaire was used as the supporting data of the test result to know the level of students' metacognition ability.

The problem on the test sheet consists of 4 questions that have met the valid and reliable criteria. In each of the questions developed, it contains three description questions to analyze students' metacognition ability in solving science literacy problem. The assessment rubric on the test sheet was adopted from indicators made by Rompayom et al ie 1) Declarative Knowledge, 2) Procedural Knowledge, 3) Conditional knowledge [19]. Scoring rubric for measuring students' metacognition knowledge level can be seen in Table 2.

Table 2. Scoring Criteria of Metacognition Knowledge

\begin{tabular}{|c|c|c|c|}
\hline \multirow{2}{*}{ Score } & \multicolumn{3}{|c|}{ Description of Metacognition Knowledge } \\
\hline & Declarative Knowledge & Procedural Knowledge & Conditional Knowledge \\
\hline 0 & $\begin{array}{c}\text { Nothing relevant to the task. The } \\
\text { students does not describe what the task } \\
\text { related }\end{array}$ & $\begin{array}{l}\text { Students do not describe which strategy } \\
\text { they use to solve a problem, and how } \\
\text { they solve that problem }\end{array}$ & $\begin{array}{l}\text { Students do not explain when and why } \\
\text { to use strategies in solve problem }\end{array}$ \\
\hline 1 & $\begin{array}{l}\text { Student write nonspecific statements } \\
\text { that are relevant to content, but not } \\
\text { related to the question }\end{array}$ & $\begin{array}{l}\text { Students seem to understand of the task } \\
\text { purpose, but they make non specific } \\
\text { statements that are not related or } \\
\text { connected between given information } \\
\text { and question }\end{array}$ & $\begin{array}{c}\text { Student list general strategies used to } \\
\text { solve a problem, but they do not explain } \\
\text { when or why to use that strategies or } \\
\text { nonspecific statement }\end{array}$ \\
\hline 2 & $\begin{array}{l}\text { Student has a clear overview of what } \\
\text { the task related to }\end{array}$ & $\begin{array}{l}\text { Student has clearly defined which } \\
\text { strategy they use. Students explicitly } \\
\text { consider to the implication between } \\
\text { given information and the question }\end{array}$ & $\begin{array}{l}\text { The student generates clearly when and } \\
\text { why to use strategies they use to solve } \\
\text { problem. The overview of their strategy } \\
\text { connects concretely to the given } \\
\text { information and the question }\end{array}$ \\
\hline
\end{tabular}

The analysis of metacognition rate profile of students in solving science literacy was done after giving a score based on indicator score in Table 1. The data was calculated to determine the number of students metacognition. The amount of knowledge metacognition students obtained will be grouped by category of metacognition level of students in Table 3.

Tabel 3. Category of Level Metacognition Based on Score Metacognition Knowledge

\begin{tabular}{llc}
\hline No & Level Metacognition & Interval of Score Metacognition Knowledge \\
\hline 1 & Tacit Use & Score Metacognition Knowledge $\leq 1$ \\
2 & Aware Use & $1<$ Score Metacognition Knowledge $\leq 2$ \\
3 & Strategic Use & $3<$ Score Metacognition Knowledge $\leq 4$ \\
4 & Reflective Use & $5<$ Score Metacognition Knowledge $\leq 6$ \\
\hline
\end{tabular}

\section{RESULTS AND ANALYSIS}

The material on the test sheet used in this study is static fluid. This is because static fluid material occurs a lot in everyday life but students still often experience misunderstandings on static fluid material [20]. This is because a static fluid material has the characteristics of conceptual analysis that allows students to link physics concepts with natural phenomena and requires the ability to infer which includes the ability to analyze, evaluate, and create [21, 22]. Results of student answers on the test sheet can measure students 'science literacy and students' metacognition abilities.

\subsection{Profile of student scientific literacy}

There are 4 categories of students' science literacy measured in this research that is science a body of knowledge, science a way of thinking, science a way of investigating and interaction of science, technology , and society. The results of the achievement of student science literacy in each category can be seen in Figure 1. 


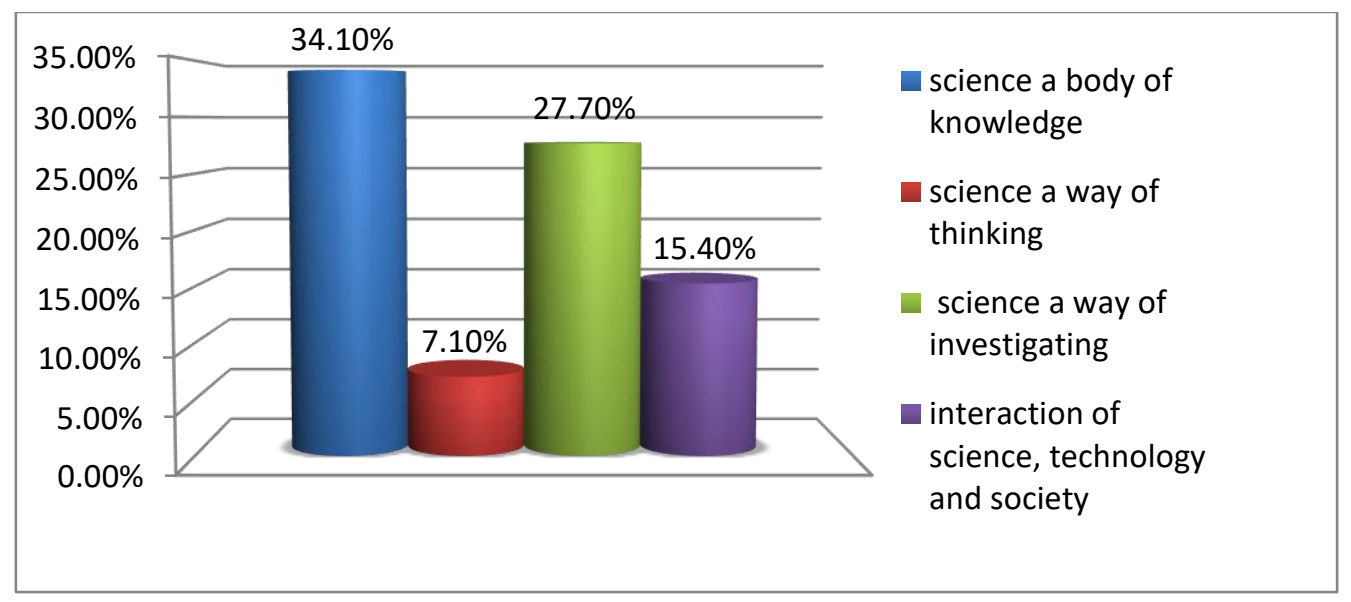

Figure 1. Percentage achievement of student scientific literacy in each category

In Figure 1, it can be seen that the achievement of science literacy of students in each category is still low. Literacy of science in the category of science a body of knowledge is still low with the percentage of achievement of $34,1 \%$. This shows that students still have difficulty in explaining the concept, principle, and law of static fluid that is the concept of hydrostatic pressure on the U-related pipe. Literacy of science in category of science a way of thinking gets the lowest achievement value that is equal to $7,1 \%$. This suggests that students still have difficulty making calculations of the volume ratio of objects if dipped in two different fluids. This is because students are still having difficulty in analyzing the law of Archimedes on the problem. Science literacy in science a way of investigating category is still low with a percentage of achievement $27,7 \%$. This shows that students are still having difficulty in reading the position and pressure relations table and provide cause and effect relationship based on the data contained in the table. Literacy of science in the category of an interaction of science, technology, and society is still low with the percentage of achievement of $15.4 \%$. This shows that students still do not understand the application of static fluids in everyday life such as a hydraulic jack.

The low science literacy of students is due to the lack of trained students in solving the problems with the characteristic of science literacy. Teachers only use judgments that emphasize content rather than on science literacy such as applying science in everyday life, thinking about problem-solving, and the ability of the process of science. This is supported by Noviani et al that teachers prefer students to be proficient in material mastery [23]. This is supported also by Juliyanto et al that the instrument of learning evaluation made more measurable how many students in mastering the material [24].

\subsection{Profile of students metacognition level in solving scientific literacy}

The low ability of students in solving the science literacy problem due to the level of metacognition ability of students is still low. This is because the ability of metacognition makes students trained to always design the best strategy in choosing, remembering, recognizing, organizing the information it faces, as well as in solving problems. There are 4 levels of metacognition ability of students in solving science literacy measured in this research that is tacit use, aware use, strategic use, reflective use. Percentage of students' metacognition ability level in solving science literacy problem can be seen in Figure 2.

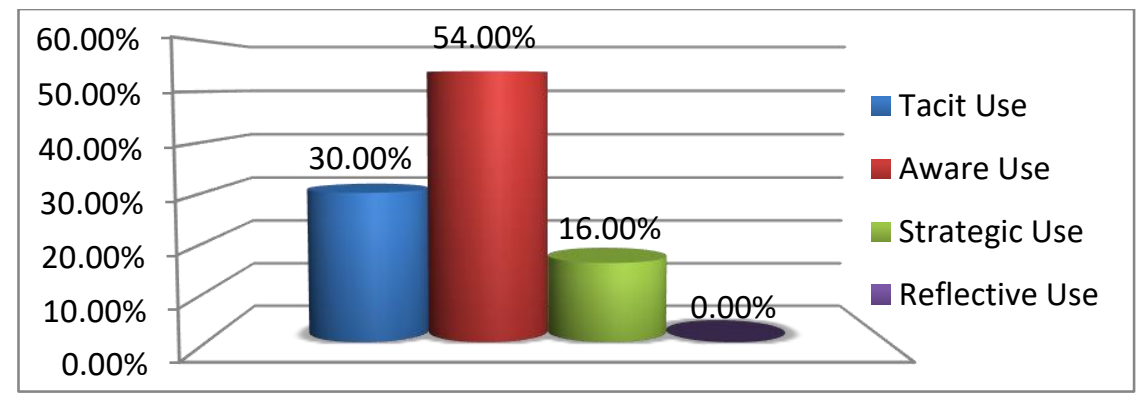

Figure 2. Percentage of students' metacognition level in solving scientific literacy 
In Figure 2 it can be seen that the percentage of students who have metacognition level at the level of tacit use is $30 \%$. This shows that $30 \%$ of learners solve the problem without thinking in making decisions. In this case, the student does not answer the question (procedural knowledge) or answer the question but not according to the question. This is because students do not understand the question (declarative knowledge) so that students only answer in trial and error and answer in solving the problem.

Percentage of students who have metacognition ability level at the aware use level is $54 \%$. This shows that $54 \%$ are aware of their own thought processes. This can be seen from the way students use prior knowledge to connect with the material (declarative knowledge). But students are still trying to relate the information they have to determine the problem-solving steps (procedural knowledge) so that students still have errors in determining the settlement step.

Percentage of students who have metacognition ability level at the strategic use level is $16 \%$. This shows that $16 \%$ of students are able to manage the thinking process to improve the accuracy of their thinking. In this case, the student is aware of her own thought process by using specific strategies that can improve the accuracy of her thinking. In this case, the student is aware and able to select specific strategies or skills to solve the problem, but can not explain the reason why to choose the step.

Percentage of students who have metacognition ability level at the strategic reflective use level is $0 \%$. This shows that no student is aware of his own thought process. This can be seen from the way students use prior knowledge to connect with the material (declarative knowledge). Students at this level can reflect on the thinking process before and after or during the process of solving the problem. Then consider the continuation and improvement of his thinking results so that the problem-solving answers are highly structured (procedural knowledge) because of students immediately correct when there are fewer steps. Students at this level can also explain the reasons why they chose to solve the problem.

The level of metacognition ability of students in solving the problem of science literacy needs to be analyzed further related to the level of metacognition ability of students in solving science literacy problem in each category. This is because knowledge of metacognition that dominates in solving each category of science literacy is different. Percentage of students metacognition ability level in solving each category of science literacy can be seen in Figure 3.

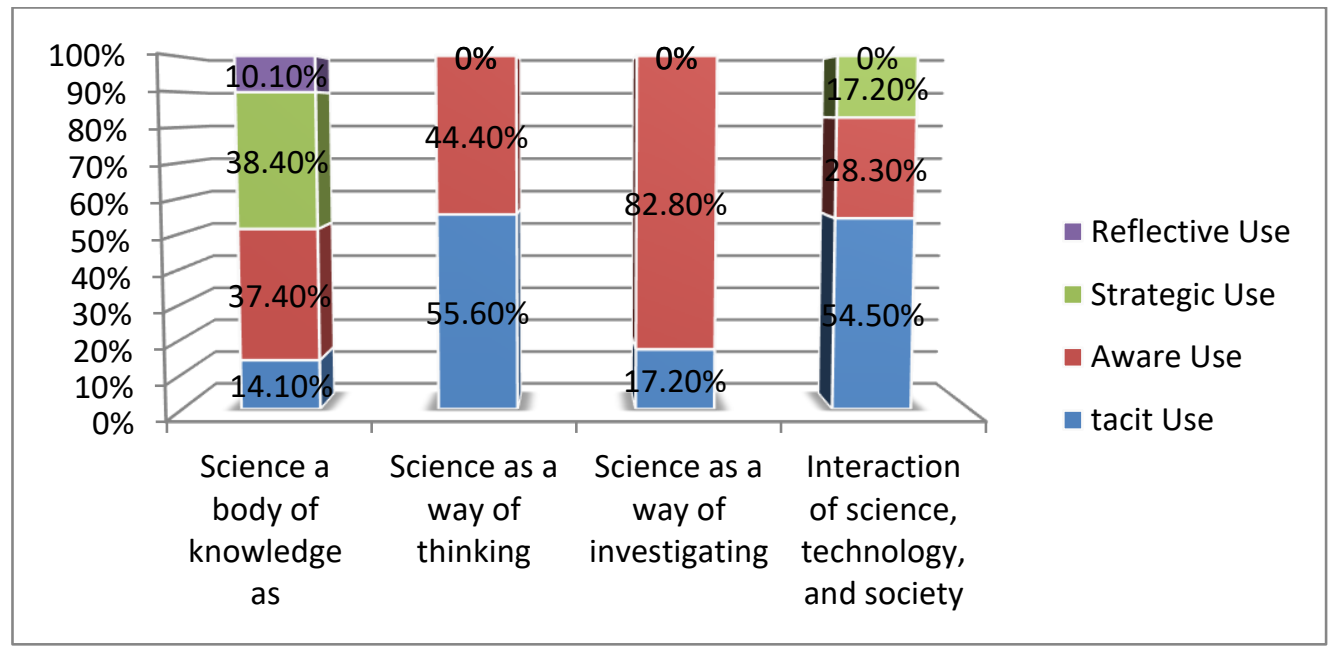

Figure 3. Percentage of students metacognition ability level in solving each category of science literacy

In Figure 3 it can be seen that the percentage of students' metacognition ability level in solving each category of science literacy is different. In the category of science literacy as a body of knowledge obtained data that the percentage of students on the level of tacit use is $14.1 \%$. This shows that $14.1 \%$ of students do not have declarative knowledge that causes students to answer the problem by trial and error. The percentage of students at the level of aware use is $37.4 \%$. This shows that $37.4 \%$ of students have declarative knowledge that causes students have the ability to mention and explain the concept, but students still do not have the procedural knowledge that causes students' critical thinking skills in the inference stage is still experiencing difficulties so that students have not been able to propose settlement steps. Percentage of students at the strategic use level is $38.4 \%$. This shows that $38.4 \%$ of students have declarative and procedural knowledge that causes students to have the ability to mention and explain concepts and propose resolution steps. But the 
students still do not have conditional knowledge that causes the students have not been able to provide the reasons for the selection of settlement steps and have not been able to improve the results of his thinking. Percentage of students at a reflective use level is $10.1 \%$. This shows that $10.1 \%$ of students have procedural, declarative and conditional knowledge that causes students to have the ability to explain concepts, propose settlement steps, and provide reasons for choosing the steps and evaluating the solution to the given problem.

In the science literacy category as a science a way of thinking, it is found that the percentage of students on tacit use level is $55.6 \%$. This shows that $55.6 \%$ of students do not have declarative knowledge that causes students to answer the problem by trial and error. The percentage of students on the awareness level was $44.4 \%$. This shows that $44.4 \%$ of students have declarative knowledge that causes students have the ability to mention and explain the concept, but students still do not have procedural knowledge that causes students have not been able to propose the settlement. Percentage of students at the strategic use and reflective use level is $0 \%$. This indicates that no student has procedural and conditional knowledge that causes the student does not have the ability to propose settlement measures so that the student can not give the reason for the selection of the settlement step and make improvements to the outcome of his thinking. One of the factors causing the absence of students who have tacit use and strategic use in solving science literacy problem science a way of thinking category is the incompetence of students in solving comparative problems on legal concepts of Archimedes. This is because the questions that have been given in relation to the law of Archimedes are only a matter of calculating the buoyant force and the condition of the object so that the students are confused when faced with a comparison problem.

In the category of science literacy as a science a way of investigating data obtained that the percentage of students on the level of tacit use is $17.2 \%$. This shows that $17.2 \%$ of students do not have declarative knowledge that causes students to answer the problem by trial and error. Percentage of students at the level of aware use was $82.8 \%$. This shows that $82.8 \%$ of students have declarative knowledge that causes the students have the ability to mention and explain the concept, but the students still do not have procedural knowledge so that students have not been able to propose settlement steps. Percentage of students at the strategic use and reflective use level is $0 \%$. This indicates that no student has procedural and conditional knowledge that causes the student does not have the ability to propose settlement measures so that the student can not give the reason for the selection of the settlement step and make improvements to the outcome of his thinking. One of the factors causing the absence of students who have tacit use and strategic use in solving science literacy problem of science a way of investigating category is the students' uncertainty in analyzing tables of observations related to position and pressure relationship. This is because the questions that have been given related to hydrostatic pressure is only a matter that calculates the hydrostatic pressure of the object so that students are confused when faced with the matter of a table of observations.

In the category of science literacy as an interaction of science, technology and society obtained data that the percentage of students on the level of tacit use is $54.5 \%$. This shows that $54.5 \%$ of students do not have declarative knowledge that causes students to answer the problem by trial and error. The percentage of students at the aware use level was $28.3 \%$. This shows that $28.3 \%$ of students have declarative knowledge that causes students have the ability to mention and explain the concept, but the students still do not have procedural knowledge so that students have not been able to propose settlement steps. Percentage of students at the strategic use level was $17.2 \%$. This shows that $17.2 \%$ of students have declarative and procedural knowledge that causes students to have the ability to explain concepts and propose resolution steps. But the students still do not have conditional knowledge that causes the students have not been able to provide the reasons for the selection of settlement steps and have not been able to improve the results of his thinking. Percentage of students at a reflective use level is $0 \%$. This indicates that no student has a conditional knowledge that causes the student has not been able to evaluate the solution to the given problem. This is indicated by the errors of students in interpreting the cross-sectional area of pascal law.

\section{CONCLUSION}

Based on the description of the results and the discussion above, it can be concluded that the achievement of science literacy in the category of science as a body of knowledge, science as a way of thinking, science a way of investigating, science as an interaction between technology and society is below $35 \%$. This is due to almost student occupy in low metacognition level that is $30 \%$ students in tacit use level, $54 \%$ students in aware use level, and only a few students occupy in high metacognition level that is $16 \%$ students in strategic use level and $0 \%$ student in reflective use level. Based on the results of research that has been implemented, suggestions that can be given as follows, learning strategies used in the learning process should be able to develop skills and literacy science learners, but it should also be supported by the assessment for monitoring and evaluation related skills and literacy science students. 


\section{ACKNOWLEDGEMENTS} the research.

Thank you also to the principal and physics teacher of SMA Batik 2 Surakarta for the availability of

\section{REFERENCES}

[1] Wulandari, N. and Shilihin, H., "Analysis of science literacy ability in the aspects of knowledge and competence of science of middle school students on the topic of calor," Edusains, vol. 8, no. 1, pp. 66-73, 2016.

[2] Ogunkola, J., "Scientific literacy : conceptual overview, importance and strategies for improvement," Jounal of Educational and Social Research, vol. 3, no. 1, pp. 265-274, 2013.

[3] Rusilowati, A., Kurniawati, L., Sunyoto, E., and Widyatmoko, A., "Developing an Instrument of Scientific Literacy Assessment on Cycle Theme," International Journal of Environmental \& Science Education, Vol. 11, no. 12, pp. 5718-5727, 2016.

[4] Gallagher, J. and Harsch, G., "Scientific literacy: science education and secondary school students", Scientific literacy International Symposium, pp. 13-34, 1997.

[5] Bybee, R., W., "Towards an understanding of scientific literacy," Scientific Literacy International Symposium, pp. 37-68, 1997.

[6] Holbrook, J. and Rannikmae, "The meaning of science literacy," International Journal of Environmental \& Science Education, vol. 4, no. 3, pp. 275-288, 2009.

[7] DeBoer, G., E., "Scientific literacy: another look at its historical and contemporary meanings and its relationship to science education reform," Journal of Research in Science Teaching, vol. 37, no. 6, pp. 582-601, 2000.

[8] Chiapetta, E., Filman, and Sethna, G, "A method to quantity major themes of scientific literacy in science textbooks," Journal of Research in Science Teaching, vol. 28, no. 8, pp. 713-725, 1991.

[9] Udeani, "Quantitative Analysis of Secondary School Biology Textbooks for Scientific Literacy Themes," Research Journal in Organizational Psychology and Educational Studies, vol. 2, no. 1, pp. 39-43, 2013.

[10] Husamah, "Blended project based learning: metacognitive awareness of biology education new students," Journal of Education and Learning, vol. 9, no. 4, pp. 274-281, 2015.

[11] Aljaberi and Gheith, "University students level of metacognitive thinking and their ability to solve problems," American Journal of Contemporary Research, vol. 5, no. 3, pp. 121-134, 2015.

[12] Sophianingtyas and Sugiarto, "identification of students metacognitive level in solving stoichiometry problem," Unesa Journal of Chemical Education, vol. 2, no. 1, pp. 21-27, 2013.

[13] Wilson, N., S. and Bai, "The relationships and impact of teacher metacognitive knowledge and pedagogical understanding of metacognition," Metacognition and Learning, vol. 5, no. 3, pp. 269-288, 2010.

[14] Flavel, "Metacognition and cognitive monitoring: a new area of cognitive developmental inquiry," American Psychologist, vol. 34, pp. 906-911, 1979.

[15] Reeve, R. and Brown, A., "Metacognition reconsidered: implications for intervention research," Journal of Abnormal Child Psychology, vol. 13, no. 3, pp. 343-356, 1985.

[16] Laurens, Theresia, "Valid student metacognition gap and reliability," Journal of Education and Learning, vol. 17, no. 2, pp. 201-213, 2010.

[17] Rahayu, P., "Students metacognition level through implementation of problem based learning with metacognitive strategies at sman 1 manyar," Unesa Journal of Chemical Education, vol. 1, no. 1, pp. 164-173, 2012.

[18] Biemer, P., P. and Lyberg, L., E., Introduction to survey quality, New Jersey: John Wiley \& Sons, Inc, 2003.

[19] Rompayom, Tambunchong, Wongyuonoi, and Dechsri, "The development of metacognitive inventory to measure students metacognitive knowledge related to chemical bonding conceptions," Association for Educational Assesment, pp. 1-8, 2010.

[20] Sulasih, Suparmi, and Sarwanto, "Profile of student critical thinking ability on static fluid concept," Journal of Physics: Conf. Series 909012060 , pp. 1-8, 2017.

[21] Rahmawati, Suparmi, and Sunarno, "Students concept understanding of static fluid based on the types of teaching," Journal of Physic : Conf. Series 983 012029, pp. 1-6, 2017.

[22] Puspita, Kaniawati, Suwarmaa, "Analysis of critical thinking skills on the topic of static fluid," Journal of Physics: Conf. Series 895 012100, pp. 1-4, 2017.

[23] Noviani, Hartono, Rusilowati, "Analysis of student mindset in completing science questions in terms of critical and creative thinking ability and science literacy," Journal of Innovative Science Education, vol. 6, no. 2, pp. 147-154, 2017.

[24] Juliyanto, Hartono, and Wiyanto, "Physics learning to grow deductive hypotetical thinking abilities in high school students," Journal of Indonesian Physics Education, vol. 7, no. 2, pp. 17-22, 2011. 


\section{BIOGRAPHIES OF AUTHORS}

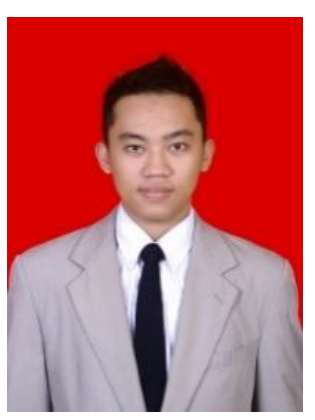

Zakaria Sandy Pamungkas S.Pd He received her bachelor degree in Major Mathematics and Science Education, The Program Physical Education, Faculty of Teaching and Learning, Jember University. He is a teacher of physics at SMA Batik 2 Surakarta. He is also a student in magister of physics education in Sebelas Maret University.

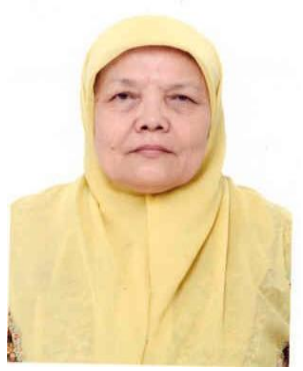

Dr. Nonoh Siti Aminah, S.Pd, M.Pd She received her bachelor degree at IKIP Yogyakarta in 1980, a master degree at IKIP Jakarta in 1995 and doctoral degree at Yogyakarta University in 2011 with a dissertation about characteristics method of equipment test for dichotomous data. She became a member of HEPI ( Himpunan Evaluasi Pendidikan Indonesia). In 2012, she got Charter award for achievement of Doctoral Degree in the field of education research and evaluation in UNY. Her research interests in assessment and evaluation.

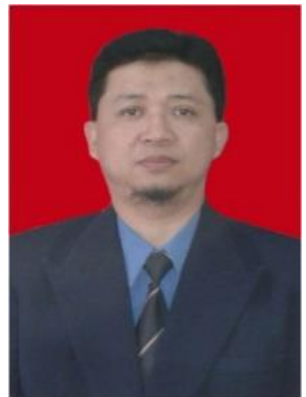

Dr. Fahru Nurosyid S.Si, M.Si He received bachelor degree, master degree, and doctoral degree in Gajah Mada University. He becomes the head of the physics program in Sebelas Maret University. He had become an author/co-author of the international conference: $10^{\text {th }}$ Joint Conference on Chemistry, ICOPIA, ICSAS, and ICE-SEAM. His research interest in electronic materials and energy. 